\title{
Infection of Rice Seed Grown in Arkansas by Pyricularia grisea and Transmission to Seedlings in the Field
}

\author{
C. Guerber, Research Specialist, and D. O. TeBeest, University Professor, Department of Plant Pathology, Univer- \\ sity of Arkansas, Fayetteville 72701
}

\begin{abstract}
Guerber, C., and TeBeest, D. O. 2006. Infection of rice seed grown in Arkansas by Pyricularia grisea and transmission to seedlings in the field. Plant Dis. 90:170-176.

Rice blast, caused by Pyricularia grisea, is an important and serious disease of rice (Oryza sativa) in the southeastern United States. The disease sporadically reaches epidemic proportions on susceptible cultivars within fields and over large areas within Arkansas. The main overwintering sources of inoculum reportedly include infected rice stubble, related host species, and infected seed. The objectives of the research were to (i) determine whether rice seed grown in Arkansas were infected with $P$. grisea, (ii) investigate the relationship between seed infection and seedling disease, and (iii) determine if planting naturally infected seed could lead to the subsequent development of rice blast on seedlings in the field. The results of seed assays showed that $P$. grisea was detected in samples of foundation, certified, and production seed. Estimated levels of infection by $P$. grisea of rice seed from 66 samples of rice seed grown in Arkansas ranged from 0 to $10.5 \%$. Planting infected seed in the greenhouse and the field resulted in seedling infection. Planting naturally infected seed may result in disease development (i) from seedlings grown from infected seed planted beneath the soil surface, (ii) from seedlings grown from germinating seed left on the soil surface, (iii) from seed coats, or (iv) from nongerminated seed left on the soil surface after planting. Additional research is necessary to establish the mechanisms of infection of seedlings and to establish disease thresholds for this important fungal pathogen of rice.
\end{abstract}

Additional keywords: seed transmission

Rice (Oryza sativa L.) is grown in several states of the United States, including Arkansas. Rice blast, caused by Magnaporthe grisea (T. T. Hebert) Barr. (anamorph: Pyricularia grisea (Cooke) Sacc.), is a serious disease of rice in temperate and tropical regions throughout the world, including the southern United States. Although epidemics of this disease are sporadic, rice blast has caused significant yield losses in Arkansas (10). The disease currently is managed by the use of resistant cultivars, proper fertilization, water level management, and prophylactic treatment with fungicides when necessary (7). None of these methods are completely effective in controlling the disease.

Because the disease recurs each year, identifying the sources of primary inoculum may help to reduce the incidence and severity of rice blast epidemics. Several overwintering sources of inoculum of the fungus have been identified $(1,17)$. In-

Corresponding author: D. O. TeBeest

E-mail: dtebeest@uark.edu

Present address of C. Guerber: Crop, Soils and Environmental Science Department, University of Arkansas, Fayetteville 72701.

Accepted for publication 23 August 2005.

DOI: 10.1094/PD-90-0170

(C) 2006 The American Phytopathological Society fected seed provide a plausible explanation for the random distribution of rice blast within Arkansas fields (11). Seedling blast originating from seedborne infection has increased in Japan as mechanized transplanting has become popular, and the level of transmission from seed to seedlings was greater from diseased seed sources grown in "box" nurseries (20).

$P$. grisea has been identified as an economically important seedborne pathogen of rice (2). Although the seedborne nature of $P$. grisea has been widely reported based on seed health testing methods and summaries (1-3,14-16), few reports have documented the natural colonization of the seed and the subsequent infection of the seedling. Chung and Lee (6) detected $P$. grisea sporulating after surface sterilizing and incubating naturally infected rice seed, and determined that $P$. grisea internally colonized the pericarp and the endosperm as mycelium and externally colonized and sporulated in the sterile glumes. Bernaux (5) observed that the internal surfaces of the lemma and palea of naturally infected rice seed were colonized by mycelium, conidia, and conidiophores. Suzuki $(18,19)$ determined that the rice blast fungus could be transmitted from artificially infested seed to seedlings in the greenhouse.

In a previous study, 8 of 25 samples of rice from Arkansas, Louisiana, and Texas were infected by $P$. grisea (9). Based on blotter tests, seed infection ranged from 1 to $40 \%$ among samples (9). Recently, greenhouse experiments conducted on one seed sample with $21 \%$ seed infection resulted in $4 \%$ seedling infection (12). Seed transmission rarely was found when seed were covered completely with soil and never in seedlings raised under waterseeded conditions (9). In 1997, Mew (13) reported that the frequency of rice blast in more than 26,000 seed lots ranged from 1.6 to $10.7 \%$, whereas the rate of seedling infection for the same seed lots in the greenhouse ranged from 1.0 to $6.2 \%$.

Previous reports indicate that $P$. grisea is seedborne. More recent information suggested that primary inoculum is dispersed randomly within fields in Arkansas (11). The objectives of this research were to (i) quantify the extent to which rice seed currently grown in Arkansas is infected by $P$. grisea, (ii) investigate the relationship between seed infection and seedling disease in the greenhouse, and (iii) determine whether naturally infected seed can lead to the subsequent development of rice blast in seedlings in the field.

\section{MATERIALS AND METHODS}

Seed from several sources and of different quality certifications were used in this study. In this report, foundation seed refers to seed produced by the Foundation Seed Program of the University of Arkansas, Division of Agriculture. Registered seed refers to seed produced from foundation seed by registered seed producers under guidelines established in Arkansas for the purpose of increase and resale to rice producers. Growers' seed refers to seed produced by an individual grower for the purpose of sale or for replanting his own fields. Growers' seed normally is not certified.

Evaluation of detection methods. In the first preliminary assay, seed of a susceptible rice cultivar, M201, grown in Arkansas (naturally blast-infected) and California (blast-free) were assayed in blotter tests under several conditions slightly modified from those reported by the Commonwealth Mycological Institute (1). For each seed source, 15 seed were placed on three layers of sterilized, moistened Whatman no. 4 filter papers in each of 14 glass petri plates $(9 \mathrm{~cm})$ and incubated in plastic boxes under lights (12-h day length, GE FT20T12-BL, black light) at $24^{\circ} \mathrm{C}$. From 3 to 10 days after plating, 210 seed were examined daily under a 
stereomicroscope for the presence of conidiospores of $P$. grisea. The test was replicated three times and the final percent infection was determined as the average of the three replications. The above experiment was repeated twice with seed incubated under cool white fluorescent lights (GEF20T10CW). A second preliminary assay was conducted using nine rice seed lots collected from several seedgrowing locations in Arkansas to determine whether $P$. grisea could be detected on seed grown in Arkansas during the sample years. The samples were incubated under cool white light as described above.

Visualization of $P$. grisea on seed, seedlings, and seed coats. Seed, seedlings, and seed coats collected from field samples were visually inspected daily for evidence of sporulation of $P$. grisea until 4 days after the samples were placed on moistened filter paper as described above. Photographs of infected seed and seedlings were taken under a Wilde-Heerbrugg stereomicroscope fitted with a Zeiss model C35 camera.

Laboratory experiments. Sixty-six seed lots representing bulk samples of foundation, registered, and grower seed, grown in 1996 and 1997, were obtained from cooperators and assayed by blotter tests for the presence of $P$. grisea on seed. Samples of foundation seed were obtained from the University of Arkansas Foundation Seed Program, Fayetteville, AR. Samples of registered and growers' seed were obtained from rice producers at the time of planting in spring 1997 and 1998. In all, 33 seed lots were examined from the 1996 harvest year and 33 were examined from the 1997 harvest year.

In all, 7 foundation seed lots from cvs. Alan, Bengal, Cypress, Drew, Kaybonnet, Lagrue, and RU 96-1188 and 10 lots of registered seed that included cvs. Alan, Bengal, Cypress, Drew, Kaybonnet, and Lagrue were collected in 1996 and were assayed by the blotter method for the incidence of $P$. grisea. Sixteen seed lots, obtained from growers replanting their own seed and harvested in 1996, representing cvs. Bengal, Cypress, Kaybonnet, Lagrue, and Newbonnet, also were assayed.

Thirty-three lots of registered seed of cvs. Bengal, Cypress, Drew, Jefferson, Kaybonnet, and Lagrue, collected at the end of the 1997 harvest year, were assayed for rice blast. Samples of foundation and growers' seed were not collected in 1997. In addition to foundation, registered, and growers seed, one seed lot of cv. M201 was obtained from seed harvested from field plots heavily infected by rice blast after being grown at the Pine Tree Station.

Two replicate samples of 200 seed were collected randomly and assayed from each of the 66 rice seed lots. Twenty seed were placed into each of 10 glass petri plates ( 9 $\mathrm{cm}$ ) on three circles of Whatman no. 4 filter paper and moistened with sterile distilled water. All plates were placed in plastic boxes and incubated at $24^{\circ} \mathrm{C}$ for 10 days in alternating light and dark cycles (12 h) under a single GE F20T10CW cool white fluorescent lamp. After 4 days, all plates were examined under a stereoscope for the presence of several fungal pathogens, including $P$. grisea. Conidia of these fungi were mounted on glass slides in water and examined under a compound microscope to identify them to genus. Percent infection by $P$. grisea was calculated for each seed lot as the number of seed infected by this fungus divided by the total number of seed examined (200) and multiplied by 100 . The final percent infection for each seed lot was determined as an average of the two replicates.

Greenhouse experiments. Greenhouse experiments were conducted to determine whether infected rice seedlings could be detected following planting of infected rice seed in "flooded" or "dry" conditions. Eight plastic flats (24 by 48 by $5.5 \mathrm{~cm}$ ) were filled with autoclaved soil and 100 seed from Bengal lot 25 (10.5\% blast infection) were placed on the soil surface in each flat. The flats were covered with clear plastic lids ( 27 by 53 by $7 \mathrm{~cm}$ ). In the flooded treatment, four of the eight trays were placed into shallow trays ( 40 by 60 by $2.5 \mathrm{~cm}$ ). The trays were filled with water to a depth that kept the soil surface visibly moist. In the dry treatment, the soil in the four remaining trays was moistened with water after placing the seed on the soil surface and the trays were allowed to come to dryness at the surface before they were re-watered. All flats were incubated in a greenhouse at 28 to $31^{\circ} \mathrm{C}$. After 10 days, all seed and germinated seedlings with attached seed were collected from each flat and divided into four groups by visual inspection. These groups were (i) asymptomatic seedlings, (ii) symptomatic seedlings (seedlings with necrotic lesions), (iii) dead seedlings, and (iv) nongerminated seed. Seed and seedlings then were incubated for 10 days as described above for the seed assay. The experiment was repeated three times. Each seed and seedling was examined under a stereoscope at $\times 14$ to $\times 60$ magnifications for the presence of $P$. grisea and other fungi at 4 and 10 days after collecting samples from flats. To confirm identifications, conidia were examined at $\times 10$ to $\times 400$ magnifications under a compound microscope. The percentages of the total represented by (i) asymptomatic seedlings, (ii) symptomatic seedlings, (iii) nongerminated seed, and (iv) dead seedlings infected by $P$. grisea were calculated as averages of all replications and repetitions.

Field experiments. A preliminary field test to determine seed transmission was conducted in unsterilized field soil at Fayetteville, AR in fall 1998. In this test, 1,000 seed from the 1996 Bengal seed lot (no. 25) were rolled onto the soil surface in microplots of planting boxes ( 74 by 183 by $31 \mathrm{~cm}$ ). Drainage holes were cut into the bottoms of each box. Tissue samples consisting of seed and seedlings were collected when seedlings were approximately 2.5 to $4 \mathrm{~cm}$ tall. Tissue samples were placed on blotting paper as described above to determine whether $P$. grise $a$ could be found on seed and vegetative tissues.

Two separate, replicated experiments were conducted in spring 1999, the first at the Pine Tree Branch Experiment Station, Pine Tree, AR, a site located within the rice-producing region of the state, and the second at the University of Arkansas Main Agricultural Experiment Station, Fayetteville, a location which is not in the riceproducing area. At Fayetteville, four treatments consisted of seed of cv. M201, with 0 and 5\% levels of infection as determined by blotter tests, and Bengal, with $0 \%$ and $10.5 \%$ infection. Three replicates of 1,000 seed of each treatment were broadcast onto the surface of unsterilized field soil contained in the planting boxes. Nets were placed over each box to control damage caused by birds. At Pine Tree, the five treatments consisted of Bengal (lot 25) with 0,5 , and $10.5 \%$ levels of infection and M201 with 0 and 5\% levels of rice blast infection. Seed (90 g per treatment) were planted $2.5 \mathrm{~cm}$ deep into field plots of nine rows measuring $4.8 \mathrm{~m}$ long by 1.5 $\mathrm{m}$ wide. Three replicates of each treatment were planted. Samples were collected 2 and 3 weeks after planting at Fayetteville and 3 and 4 weeks after planting at Pine Tree. At each sampling date, approximately 200 to 300 seedlings per treatment were removed carefully from the soil to maintain roots, germinated seed, and vegetative tissues intact. Additionally, 50 to 100 nongerminated seed and 20 to 50 seed coats found on the soil surface for treatment were collected at each sampling time. Seedlings, seed, and seed coats initially were examined under a microscope, then washed in cold tap water to remove soil and incubated as described above.

Data analysis. Statistical analysis of all data were performed using the least significant difference procedure $(P=0.05)$ of the SAS software package (SAS Institute, Cary, NC).

\section{RESULTS}

Evaluation of detection methods and visualization of $P$. grisea on seed, seedlings, and seed coats. In the blotter tests, the observed number of seed infected by $P$. grisea appeared to reach maximum levels 4 to 5 days after seed were placed on moistened filter paper. After 5 days, the percentage of seed infected appeared to decline, possibly because of the increased growth of other fungi such as Curvularia, Penicillium, and Fusarium spp. that obscured $P$. grisea. The percentage of seed infected by the rice blast fungus appeared to be slightly higher when seed were incu- 
bated under cool white lights than when seed from the same lots were incubated under black lights. These experiments showed that the blast fungus was present in M201 rice seed grown in Arkansas but was not present in M201 seed obtained from California. In the preliminary tests on seed lots of several cultivars grown in Arkansas, the level of infection ranged from 0 to $14 \%$. The presence and location of $P$. grisea on the incubated seed and seedling structures indicates the pathogen's ability to survive within the seed and then sporulate on the plant as it develops.

Microscopic examinations of seed and seedlings colonized by $P$. grisea were conducted. A healthy rice seed assayed in a blotter test conducted in the laboratory is shown in Figure 1A, whereas an infected seed developed extensive mycelial growth of $P$. grisea on the rachilla end of the seed (Fig. 1B). Conidia of the fungus were most often observed on the rachilla, or embryonal end, of seed. A photograph of a rice seedling approximately 10 days after germination shows the coleoptile, primary and secondary leaves, root tissue, mesocotyl, and the still-attached seed (Fig. 2). Sporulation of $P$. grisea on an infected coleoptile is shown in Figure $3 \mathrm{~A}$ and $\mathrm{B}$, and photographs of $P$. grisea sporulating on the mesocotyl of an infected seedling are shown in Figure 3C and D. Sporulation of $P$. grisea on a primary leaf is shown in Figure $3 \mathrm{E}$ and $\mathrm{F}$, and sporulation on the rachilla end of a seed coat found on soil is shown in Figure $3 \mathrm{G}$ and $\mathrm{H}$. In all of the tests, sporulation was observed within 4 days after tissue samples were placed on moistened filter paper and incubated under lights.

Laboratory experiments. The level of seed infection of 35 samples of the seed of four rice cultivars (Alan, Bengal, Cypress, and Lagrue), in which one or more seed lots were infected with the rice blast fungus, in shown in Table 1. P. grisea was not detected on seed from the remaining 31 seed lots of five rice cultivars (Drew, Kaybonnet, RU 96-1188, Newbonnet, and Jefferson) that were collected and examined.

The rice blast fungus infected rice seed of susceptible cultivars in all certification classes of seed grown in Arkansas in 1996 and 1997 (Table 1). Of the 66 seed samples that were examined, $15(22.7 \%)$ were infected by $P$. grisea. The average level of infection was $1.36 \%$, with a range from 0.25 to $10.5 \%$. The highest level of infection $(10.5 \%)$ was found in the susceptible cv. Bengal (lot 25) collected as a sample from a grower's field harvested in 1996.

The rice blast fungus was found in 0.25 to $0.50 \%$ of the seed of three cultivars, Alan, Bengal, and Lagrue, among the foundation seed collected from the 1996 harvest year. It was not detected in seed of Cypress, Drew, Kaybonnet, or RU96-1188 in that harvest year.

$P$. grisea was detected in approximately $16 \%$ of the registered seed lots among samples that were grown in Arkansas during 1996 and 1997 (Table 1). Of the 10 registered seed lots collected in 1996, 3 contained infected seed. The infected seed were found in samples of two susceptible cultivars, Bengal and Lagrue. The fungus was not detected in seed from samples of Alan, Cypress, Drew, or Kaybonnet. The fungus was found in seed from 4 of the 33 registered seed lots collected from the 1997 harvest year. Infected seed were found in samples of seed of three cultivars, Bengal, Lagrue, and Cypress. The levels of infection ranged from 0.25 to $3.5 \%$. The fungus was not detected in the samples of seed from three cultivars, Drew, Jefferson, or Kaybonnet seed lots.

Seed samples were collected from growers replanting their own seed. Of the 16 growers' seed lots collected from the 1996 harvest, 5 (31.25\%) were infected with $P$. grisea. The fungus was detected in samples of two cultivars, Bengal and La-

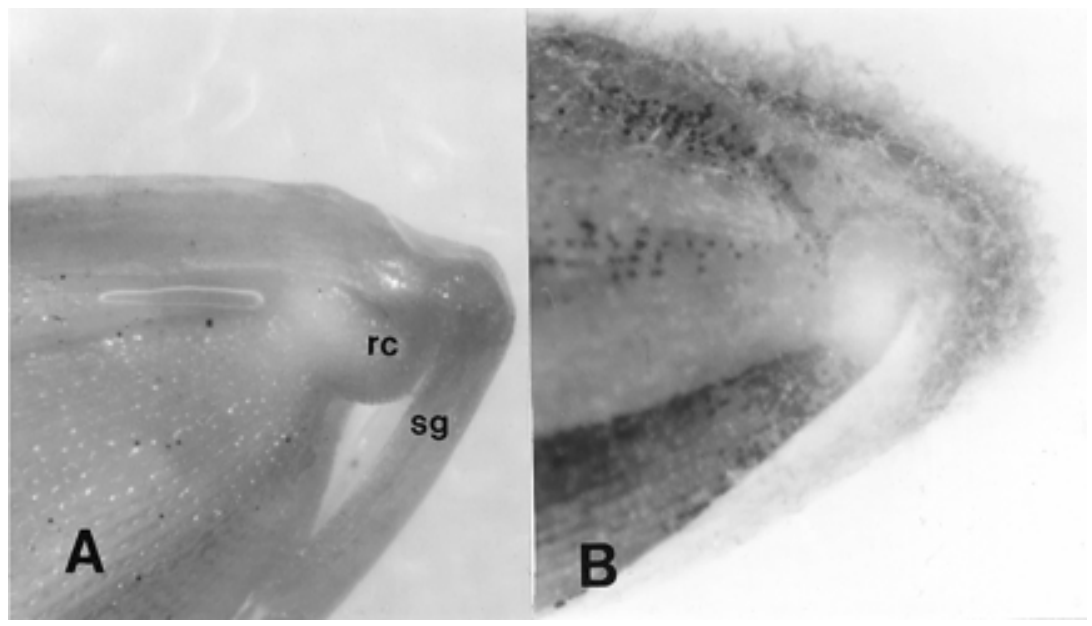

Fig. 1. Rachilla, or embryonal, end of a healthy and infected rice seed after incubation on blotting paper for 4 days. A, Sterile glumes (sg) and rachilla (rc) of a healthy seed. B, Colonization of the rachilla by Pyricularia grisea of an infected seed. Mycelium and spores of the fungus were easily identified under a compound microscope. grue, and the levels of detection ranged from 0.25 to $10.5 \%$. Infected seed were not detected in samples of Cypress, Kaybonnet, or Newbonnet. Growers' seed lots were not collected from the 1997 harvest.

Greenhouse experiments. Experiments were conducted to determine if the fungus could be detected in rice seed and seedlings after seed from an infected seed lot were planted in field soils in flats maintained under dry and flooded conditions in the greenhouse. P. grisea was detected on asymptomatic and symptomatic seedlings grown under dry conditions (Table 2). The fungus was detected in nongerminated and germinated seed in these experiments. Following incubation on blotter paper, the fungus was observed sporulating in coleoptiles and primary leaves of both symptomatic and asymptomatic seedlings when seed were planted under and maintained under the dry conditions. The fungus was detected in a larger number of seed maintained under the dry conditions than seed maintained under the flooded conditions. The fungus was not detected in rice seedlings grown in the greenhouse under the flooded conditions of the experiments (Table 2).

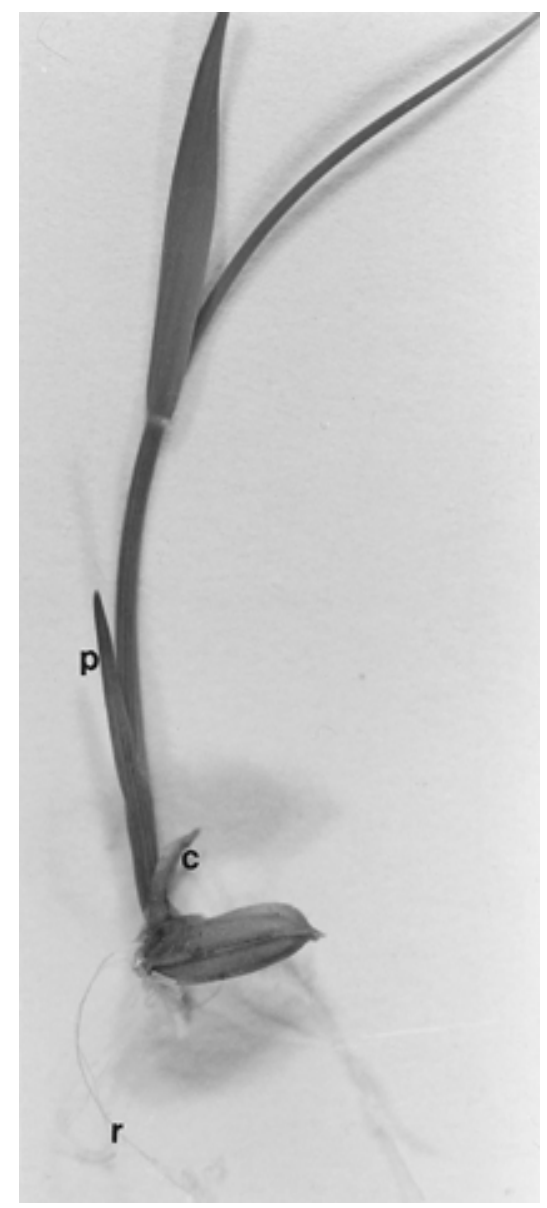

Fig. 2. Healthy rice seedling that germinated and grew from seed placed on filter paper and incubated under lights for 10 days in the blotting paper assays. Symbols, r, s, c, and p indicate root, seed, coleoptile, and primary leaf, respectively. 
Field experiments. In the preliminary test conducted in Fayetteville in fall 1998, the fungus could be found in seed and seedlings of Bengal for up to 6 weeks after planting seed on the soil surface (data not shown). Following incubation of samples collected from the field on filter paper for 4 days, the fungus sporulated from germinating seed, coleoptiles of seedlings, and densely colonized primary leaves. However, characteristic blast lesions were not observed on any of the infected seedlings during these experiments.
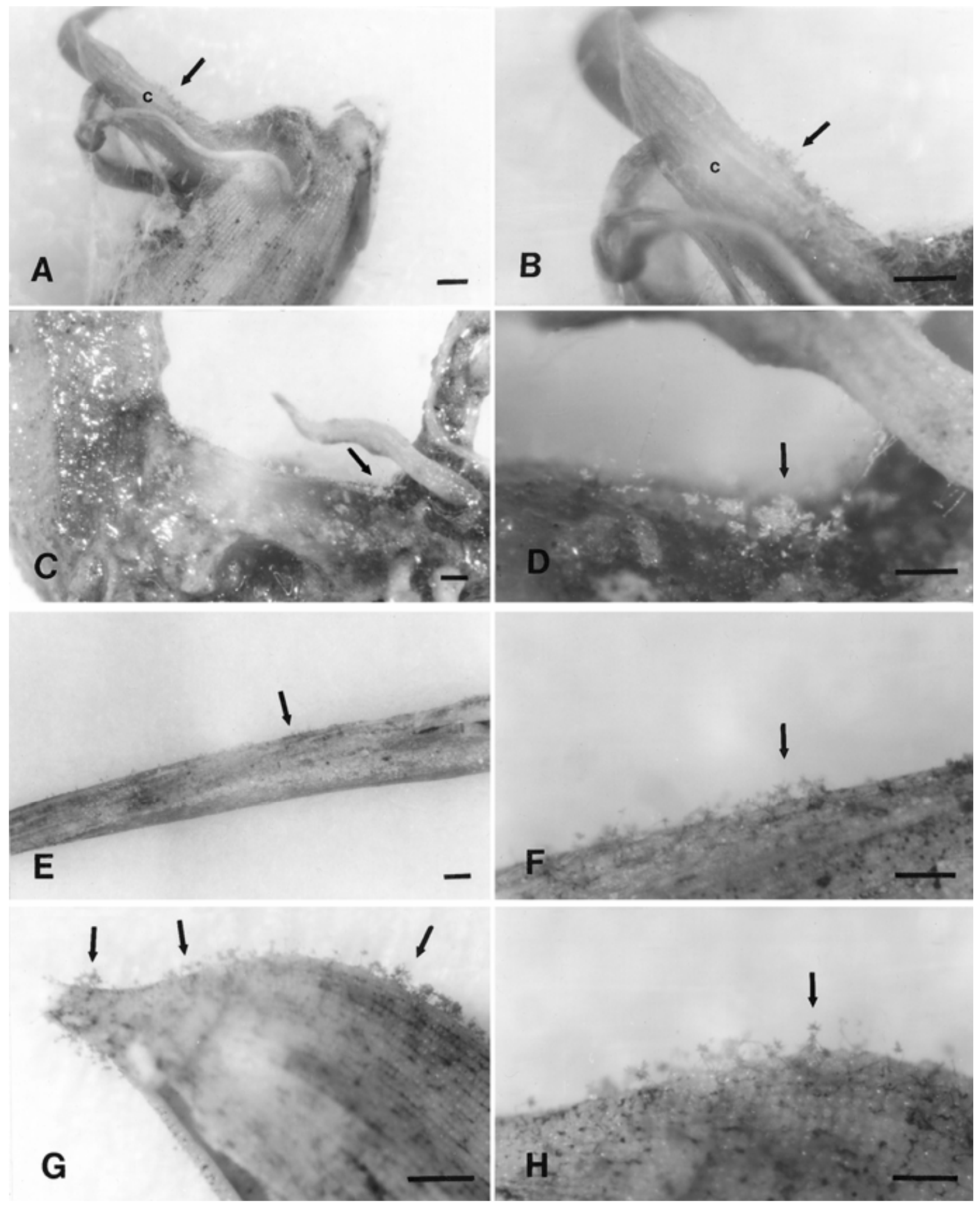

Fig. 3. Sporulation (arrows) of Pyricularia grisea on infected rice seed and seedlings. A and $\mathbf{B}$, Sporulation of the fungus on a coleoptile (c) of an infected seedling $(\mathrm{bar}=400 \mu \mathrm{m})$. C and $\mathbf{D}$, Sporulation of the fungus on the mesocotyl of a young seedling (bar $=400$ and $200 \mu \mathrm{m}$ respectively). E and $\mathbf{F}$, Sporulation of the fungus on the primary leaf of an infected seedling (bar $=400$ and $200 \mu \mathrm{m}$ respectively). $\mathbf{G}$ and $\mathbf{H}$, Sporulation of the fungus on the rachilla end of a seed coat collected from the soil surface several weeks after planting (bar $=400$ and $200 \mu \mathrm{m}$ respectively). 
The results of the experiments conducted in spring 1999 at two locations with infected seed lots of two different cultivars are shown in Table 3. P. grisea was sporulating from seedlings of M201 collected from the 5\% treatment planted at Pine Tree which were asymptomatic (i.e., without necrotic lesions). The fungus sporulated from germinated seed and from the coleoptiles and primary leaves of M201 seedlings incubated on filter paper. The fungus also was detected in nongerminated seed from the treatment infested at the 5\% level planted at the Fayetteville location. The fungus was not detected from seed or tissue samples collected from the $0.5 \%$ - or $1 \%$-infected treatments of M201 planted at either location (data not shown).

Experiments also were conducted to determine if the fungus could be found in seed and seedlings of Bengal after infected seed were planted in the field. The blast

Table 1. Percentage of rice seed infected by the rice blast fungus, Pyricularia grisea, in 35 samples harvested in 1996 and 1997 as determined by microscopic examination after incubation under lights on moistened filter paper disks ${ }^{\mathrm{z}}$

\begin{tabular}{|c|c|c|c|c|c|}
\hline \multirow[b]{3}{*}{ Seed source } & \multirow[b]{3}{*}{ Cultivar } & \multicolumn{4}{|c|}{ Harvest year } \\
\hline & & \multicolumn{2}{|c|}{1996} & \multicolumn{2}{|c|}{1997} \\
\hline & & Sample no. & Seed infected $(\%)$ & Sample no. & Seed infected $(\%)$ \\
\hline \multirow[t]{3}{*}{ Foundation } & Alan & 1 & $0.25 \mathrm{a}$ & NA & \\
\hline & Bengal & 1 & $0.50 \mathrm{a}$ & 1 & $0 \mathrm{a}$ \\
\hline & Lagrue & 1 & $0.25 \mathrm{a}$ & 1 & $0 \mathrm{a}$ \\
\hline \multirow[t]{10}{*}{ Registered } & Bengal & 1 & $0.75 \mathrm{a}$ & 1 & $0.50 \mathrm{a}$ \\
\hline & & $\ldots$ & $\ldots$ & $2-6$ & $0 \mathrm{a}$ \\
\hline & Cypress & 1 & $0 \mathrm{a}$ & 1 & $0.25 \mathrm{a}$ \\
\hline & & 2 & $0 \mathrm{a}$ & $2-6$ & $0 \mathrm{a}$ \\
\hline & Lagrue & 1 & $0.5 \mathrm{a}$ & 1 & $0 \mathrm{a}$ \\
\hline & & 2 & $3.5 \mathrm{~b}$ & 2 & $0 \mathrm{a}$ \\
\hline & & $\ldots$ & $\ldots$ & 3 & $0.25 \mathrm{a}$ \\
\hline & & $\ldots$ & $\ldots$ & 4 & $0 \mathrm{a}$ \\
\hline & & $\ldots$ & $\ldots$ & 5 & $1.50 \mathrm{~b}$ \\
\hline & & & & 6 & $0 \mathrm{a}$ \\
\hline \multirow{7}{*}{ Growers' } & Bengal & 1 & $1.0 \mathrm{a}$ & $\ldots$ & $\ldots$ \\
\hline & & 2 & $10.5 \mathrm{c}$ & $\ldots$ & $\ldots$ \\
\hline & Lagrue & 1 & $0.25 \mathrm{a}$ & $\ldots$ & $\ldots$ \\
\hline & & 2 & $0.25 \mathrm{a}$ & $\ldots$ & $\ldots$ \\
\hline & & 3 & $0.50 \mathrm{a}$ & $\ldots$ & $\ldots$ \\
\hline & & 4 & $0 \mathrm{a}$ & $\ldots$ & $\ldots$ \\
\hline & & 5 & $0 \mathrm{a}$ & $\ldots$ & $\ldots$ \\
\hline
\end{tabular}

${ }^{\mathrm{z}}$ In all, 66 samples were tested, but only samples from cultivars of the 1996 and 1997 seed lots that were infected are listed. Assay results showed that 31 seed lots did not contain infected seed after incubation on moistened filter disks, and these results are not shown. Percent seed infection is determined as the average of two separate assays of 200 seed that were incubated and examined microscopically. Percent infection was determined as the number of seed upon which spores of $P$. grisea was found divided by the number of seed observed in the test multiplied by 100 . NA = not available. All means within a column followed by the same letter are not significantly different according to the least significant difference procedure (SAS Institute) at $P=0.05$. fungus sporulated from the coleoptiles, mesocotyls, and primary leaves of asymptomatic seedlings collected 3 weeks after planting at Pine Tree (Table 3). Sporulation was observed in germinated seed and in seed coats of Bengal from samples collected 3 weeks after planting at the Pine Tree location. The fungus was found in samples of nongerminated seed, in the coleoptiles and primary leaves of the asymptomatic Bengal seedlings, and in the coleoptile and the roots of the symptomatic Bengal seedling collected 2 weeks after planting at Fayetteville. P. grisea was found in asymptomatic seedlings, nongerminated seed, and germinated seed collected at Fayetteville 3 weeks after planting. The coleoptiles, primary leaves, and root tissues of these seedlings were colonized.

Results showed that $P$. grisea was detected in seed and seedlings of susceptible rice cultivars in tests conducted in the laboratory, greenhouse, and field. These experiments have identified several sources of inoculum of $P$. grisea, including seedlings grown from (i) seed planted below the soil surface, (ii) seedlings growing from seed that germinated on the soil surface, (iii) seed coats found on the soil surface, and (iv) nongerminated seed also found on the soil surface. The fungus was not detected in seed of highly resistant cultivars.

\section{DISCUSSION}

The results of our experiments show that the rice blast fungus was found in seedlings from planted, infected seed, nongerminating seed, and seed coats that had been harvested and certified in three different certification classes in Arkansas.

In the field experiments, $P$. grisea colonized rice seedlings grown from naturally infected seed that had been planted and

Table 2. Percentage of 'Bengal' rice seed and seedlings infected by Pyricularia grisea ${ }^{\mathrm{x}}$

\begin{tabular}{l}
\hline \\
\cline { 2 - 3 }
\end{tabular}


from naturally infected seed placed on the soil surface, indicating the potential for the fungus to survive within the seed even when planted in the field. After laboratory incubation of seedlings collected in the field, $P$. grisea initially sporulated from germinated seed and coleoptiles, and on the primary leaves and roots of seedlings whether they were planted or found on the soil surface. Chung and Lee (6) detected sporulation of $P$. grisea initially at the hilum, extending to the empty glume close to the hilum, then colonizing the coleoptile. Finally, sporulation progressed to the first true leaf. They also observed the fungus growing on the coleorhiza and root tissue.

Although $P$. grisea has been reported to be seedborne, the pathway of infection of the rice seed on maturing plants under field conditions has not been fully investigated. There appear to be three possible routes of entry of the fungus into rice grains of the parent plant $(2,4)$. The first route is the colonization of spikelets from an infected boot leaf while the panicle is still enclosed within the boot. The second route is the infection of grains after panicle emergence via infected glumes. Suzuki (19) determined that, after artificial inoculation of rice plants before, during, and after flowering, the hyphae of $P$. grisea infected tissues of the embryo, endosperm, bran layer, glumes of the seed, and conidia between the glume and the caryopsis. He emphasized that the fungus sporulated from glumes with an absence of disease symptoms and from caryopses that were healthy and unhealthy in appearance. Bernaux (5) examined rice seed from plants artificially inoculated with the blast fungus before, during, and after anthesis and showed that glumes were infected during anthesis. After anthesis, sclerification of tissues within the seed prevented further infection of internal seed structures. However, conidia and hyphae remained between the glumes and the caryopses, enabling survival of the pathogen. Bernaux (5) demonstrated that $P$. grisea frequently sporulated on the coleoptiles of seedlings grown from the infected seed planted in the greenhouse. He further showed that the mycelium grew into the primary leaf and the sheaths of subsequent leaves from the coleoptile. The third route of entry of the pathogen into the grain is through the hilar region from infected vascular tissues of the mother plant. Chung and Lee (6) reported abundant sporulation of $P$. grisea at the end of the pedicel and in the hilum of dehulled seed from naturally infected seed.

Manandhar (12) found blast lesions on the second and third leaves of seedlings grown from infected seed in the greenhouse after incubation on blotters. Sporulation of the fungus also was found in asymptomatic seedlings and it has been suggested that latent infection can occur at temperatures too high or low for lesions to develop. After artificially inoculating 30day-old rice plants with $P$. grisea, conidia of the fungus were found not only in the pith cavities of rice plants but also in the internal cavities of infected leaves (21). Conidia produced in the hollow pith cavi- ties germinated readily on potato-dextrose agar. We also observed sporulation of $P$. grisea and other fungi commonly associated with our samples (i.e., Cladosporium, Curvularia, and Fusarium spp.) but only after the samples were incubated in the laboratory. We attributed the lack of sporulation prior to incubation to the conditions (i.e., low relative humidity) under which the seed and samples were stored and collected. Latent infection remains a possible explanation; however, this possibility requires additional work and histological examinations

Greater than $99 \%$ of the observed sporulation occurred where the rachilla met the sterile glumes on the seed we examined in blotter tests. Sporulation also was noted to be much higher on the rachilla (embryonal) end of infected seed in previous studies $(5,6,12,18)$. This supports the suggestion that the sterile glumes and the rachilla are the structures of harvested seed most susceptible to $P$. grisea $(12,18)$. In the present study, the remaining $1 \%$ of the seed were colonized over their entire surface.

Our field experiments suggested four potential mechanisms by which the disease cycle can be initiated from planting naturally infected seed: (i) from infected seedlings grown from infected seed that are planted, (ii) from infected seedlings that grew from germinated seed that remained on the soil surface, (iii) from seed coats, and (iv) from nongerminating seed left on the soil surface. In surveys of 18 mechanically planted rice fields, we found up to

Table 3. Percentage of rice seed and seedlings grown from seed of cvs. M201 and Bengal that were naturally infected by Pyricularia grisea

\begin{tabular}{|c|c|c|c|c|c|c|c|c|}
\hline \multirow[b]{2}{*}{ Location, cultivar } & \multirow[b]{2}{*}{ Weeks $^{\mathrm{x}}$} & \multirow[b]{2}{*}{ Initial $(\%)^{y}$} & \multicolumn{3}{|c|}{ Seedlings infected $(\%)^{\mathrm{v}}$} & \multicolumn{2}{|c|}{ Seed infected $(\%)^{\mathrm{w}}$} & \multirow[b]{2}{*}{ Coats $(\%)^{\mathrm{z}}$} \\
\hline & & & Asympt. & Sympt. & Dead & Nongerm. & Germ. & \\
\hline \multicolumn{9}{|l|}{ Pine Tree } \\
\hline \multirow[t]{4}{*}{ M201 } & 3 & 0 & $0 \mathrm{a}$ & $0 \mathrm{a}$ & $0 \mathrm{a}$ & $0 \mathrm{a}$ & $0 \mathrm{a}$ & $0 \mathrm{a}$ \\
\hline & & 5 & $0 \mathrm{a}$ & $0 \mathrm{a}$ & $0 \mathrm{a}$ & $0 \mathrm{a}$ & $0 \mathrm{a}$ & $0 \mathrm{a}$ \\
\hline & 4 & 0 & $0 \mathrm{a}$ & $0 \mathrm{a}$ & $0 \mathrm{a}$ & $0 \mathrm{a}$ & $0 \mathrm{a}$ & $0 \mathrm{a}$ \\
\hline & & 5 & $0.48 \mathrm{a}$ & $0 \mathrm{a}$ & $0 \mathrm{a}$ & $0 \mathrm{a}$ & $0 \mathrm{a}$ & $0 \mathrm{a}$ \\
\hline \multirow[t]{4}{*}{ Bengal } & 3 & 0 & $0 \mathrm{a}$ & $0 \mathrm{a}$ & $0 \mathrm{a}$ & $0 \mathrm{a}$ & $0 \mathrm{a}$ & $0 \mathrm{a}$ \\
\hline & & 10.50 & $0.45 \mathrm{a}$ & $0 \mathrm{a}$ & $0 \mathrm{a}$ & $0 \mathrm{a}$ & $0 \mathrm{a}$ & $8.8 \mathrm{~b}$ \\
\hline & 4 & 0 & $0 \mathrm{a}$ & $0 \mathrm{a}$ & $0 \mathrm{a}$ & $0 \mathrm{a}$ & $0 \mathrm{a}$ & $0 \mathrm{a}$ \\
\hline & & 5 & $0 \mathrm{a}$ & $0 \mathrm{a}$ & $0 \mathrm{a}$ & $0 \mathrm{a}$ & $0 \mathrm{a}$ & $0 \mathrm{a}$ \\
\hline \multicolumn{9}{|l|}{ Fayetteville } \\
\hline \multirow[t]{4}{*}{ M201 } & 2 & 0 & $0 \mathrm{a}$ & $0 \mathrm{a}$ & $0 \mathrm{a}$ & $0 \mathrm{a}$ & $0 \mathrm{a}$ & $0 \mathrm{a}$ \\
\hline & & 5 & $0 \mathrm{a}$ & $0 \mathrm{a}$ & $0 \mathrm{a}$ & $0.67 \mathrm{~b}$ & $0 \mathrm{a}$ & $0 \mathrm{a}$ \\
\hline & 3 & 0 & $0 \mathrm{a}$ & $0 \mathrm{a}$ & $0 \mathrm{a}$ & $0 \mathrm{a}$ & $0 \mathrm{a}$ & $0 \mathrm{a}$ \\
\hline & & 5 & $0 \mathrm{a}$ & $0 \mathrm{a}$ & $0 \mathrm{a}$ & $0 \mathrm{a}$ & $0 \mathrm{a}$ & $0 \mathrm{a}$ \\
\hline \multirow[t]{4}{*}{ Bengal } & 2 & 0 & $0 \mathrm{a}$ & $0 \mathrm{a}$ & $0 \mathrm{a}$ & $0 \mathrm{a}$ & $0 \mathrm{a}$ & $0 \mathrm{a}$ \\
\hline & & 10.50 & $0.31 \mathrm{a}$ & $0.31 \mathrm{~b}$ & $0 \mathrm{a}$ & $1.07 \mathrm{~b}$ & $0 \mathrm{a}$ & $0 \mathrm{a}$ \\
\hline & 3 & 0 & $0 \mathrm{a}$ & $0 \mathrm{a}$ & $0 \mathrm{a}$ & $0 \mathrm{a}$ & $0 \mathrm{a}$ & $0 \mathrm{a}$ \\
\hline & & 10.50 & $0.67 \mathrm{a}$ & $0 \mathrm{a}$ & $0 \mathrm{a}$ & $2.22 \mathrm{c}$ & $1.11 \mathrm{~b}$ & $0 \mathrm{a}$ \\
\hline
\end{tabular}

u Seed were broadcast onto the surface of soil in wooden boxes in the field at Fayetteville or mechanically drill planted at Pine Tree in 1999.

${ }^{v}$ Between 200 and 300 seedlings were assayed per treatment by placing samples on moistened filter paper for 4 days at each time interval. Asympt., Sympt., and Dead = asymptomatic, symptomatic, and dead seedlings, respectively.

${ }^{w}$ Between 50 and 100 nongerminated seed were assayed per treatment at each time interval by placing samples on moistened filter paper disks. Nongerm. and Germ. = nongerminated and germinated seed, respectively.

$\mathrm{x}$ Weeks after planting.

${ }^{y}$ Initial percent seed infected. The initial rate of seed infection was determined prior to planting by two blotter assays of 200 seed per assay. Percent infection of seed and samples in all categories was determined as the number of samples infected by $P$. grisea divided by the total number of samples multiplied by 100. All data within a column followed by the same letter are not significantly different using the least significant difference test (SAS Institute) at $P=$ 0.05. All data are the averages of four replications for each treatment and time interval.

${ }^{\mathrm{z}}$ Percent seed coats infected. Between 20 and 50 seed coats were assayed per treatment at each time interval by placing samples on moistened filter paper disks. 
400 rice seed $/ \mathrm{m}^{2}$ on the soil surface (D. O. TeBeest, unpublished information). Generally, more seed were found on the surface in the corners or along the ends of the fields, presumably as a result of mechanized planting methods. Filippi and Prabhu (8) observed that seedborne blast rarely was responsible for the onset of epidemics in Brazil, except in cases where seed were not covered by soil. In rice field plots, autoclaved rice seed artificially infested with $P$. grisea placed on the soil surface provided sufficient inoculum to support infection foci (12).

Transmission through seed is considered more important than any other survival means for many pathogens because the pathogen remains viable longer in seed than in vegetative parts or in the soil (2). Our results indicate a relationship between planting naturally infected seed and seedling infection in the field. For $P$. grisea to be transmitted by seed, it must infect seed at inoculum levels sufficient to cause rice blast in rice after planting. The actual potential of seed transmission of $P$. grisea under field conditions and determination of a disease threshold remains to be studied. Additional evidence clarifying the mechanism through which the fungus invades rice seed and plant structures from seedling emergence through grain production is necessary to determine how the disease cycle is initiated by infected seed.

\section{ACKNOWLEDGMENTS}

Research supported in part by a grant from the Arkansas Rice Research Promotion Board. We thank R. D. Cartwright, F. N. Lee, and D. H. Long for their assistance in obtaining seed and for their comments and advice during planning and execution of the research and preparation of this manuscript; and J. Dale, J. Guerber, and T. Ishibashi for the invaluable translation of journal articles.

\section{LITERATURE CITED}

1. Agarwal, P. C., Mortensen, C. N., and Mathur, S. B. 1989. Seed-borne disease and seed health testing of rice. Pages 7-14 in: Tech. Pap. No. 3, Phytopathol. Pap. No. 30. CAB International Mycological Institute, Surrey, UK.

2. Agarwal, V. K., and Sinclair, J. B. 1997. Principles of Seed Pathology. Second Edition. Lewis Publishers, New York.

3. Andrews, C. H., and Cabrera, E. R. 1995. Seed Quality. Bull. 1033, Miss. Agric. For. Exp. Stn. Mississippi State, Starkville.

4. Bandyopadhyay, R., Mughogho, L. K., and Satyanarayana, M. V. 1987. Systemic infection of sorghum by Acremonium strictum and its transmission through seed. Plant Dis. 71:647650 .

5. Bernaux, P. 1981. Evolution de la sensibilite des glumelles du riz a Pyricularia oryzae Cav. Et a Drechslera oryzae (Br. de Haan) Sub. Et. Jain: consequences pour la transmission des maladies. Agronomie 1 (4):261-264. (In French)

6. Chung, H., and Lee, C. 1983. Detection and transmission of Pyricularia oryzae in germinating rice seed. Seed Sci. Technol. 11:625637.

7. Cloud, G. L., and Lee, F. N. 1992. Rice Blast: Factors influencing severity and control strategies used to manage the disease. Univ. Ark. Coop. Ext. Publ. No. MP341.

8. Filippi, M. C., and Prabhu, A. S. 1997. Integrated effect of host resistance and fungicidal seed treatment on rice blast control in Brazil. Plant Dis. 81:351-355.

9. Lamey, H. A. 1970. Pyricularia oryzae on rice seed in the United States. Plant Dis. Rep. 54:931-935.

10. Lee, F. N. 1994. Spore sources for rice blast epidemics. Ark. Farm Res. 43(5):4-5.
11. Long, D. H. 1999. The spatial and temporal dynamics of rice blast disease in Arkansas. PhD. thesis, University of Arkansas, Fayetteville.

12. Manandhar, H. K., Lyngs Jorgensen, H. J., Smedegaard-Petersen, V., and Mathur, S. M. 1998. Seedborne infection of rice by Pyricularia oryzae and its transmission to seedlings. Plant Dis. 88:1083-1099.

13. Mew, T. 1997. Developments in rice seed health testing policy. Pages 129-145 in: Seed Health Testing. J. D. Hutchins and J. C. Reeves, eds. CAB International. Wallingford, UK.

14. Neergaard, P. 1981. Risks for the EPPO region from seed-borne pathogens. EPPO Bull. 11:207-212.

15. Neergaard, P., Lambat, A. K., and Mathur, S B. 1970. Seed health testing of rice: Testing procedures for detection of Pyricularia oryzae Cav. Proc. Int. Seed Test Assoc. 35(1):157 163.

16. Neergaard, P., and Saad, A. 1962. Seed health testing of rice. A contribution to development of laboratory routine testing methods. Indian Phytopathol. 15:85-111.

17. Ou, S. H. 1985. Pages 207-208 in: Rice Diseases. Second Edition. Commonwealth Mycological Institute, Kew, UK.

18. Suzuki, H. 1930. Experimental studies on the possibility of primary infection of Pyricularia oryzae and Ophiobolus miyabeanus internal of rice seeds. Ann. Phytopathol. Soc. Jpn. 2:245275. (In Japanese, summary in English)

19. Suzuki, H. 1934. Studies on an infection type of rice disease analogous to the flower infection. Ann. Phytopathol. Soc. Jpn. 3:1-14. (In Japanese, summary in English)

20. Tanaka, K., and Kimura, W. B. 1977. Occurrence of seed-borne Pyricularia oryzae on rice seedlings in box culture and its transmission to transplanted rice. Ann. Phytopathol. Soc. Jpn. 43:310. (In Japanese)

21. Terui, M. 1940. Internal formation of conidia of the rice blast fungus. Ann. Phytopathol. Soc Jpn. 10:265-269. 